\title{
The text-critical and exegetical value of the Dead Sea Scrolls
}

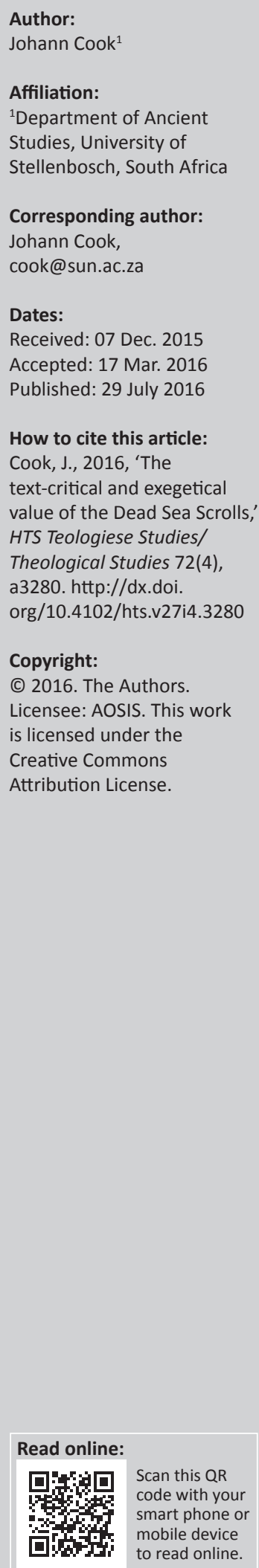

This article will analyse a number of Dead Sea manuscripts and/or fragments in order to determine their linguistic and exegetical value. The article will, firstly, address textual material that is largely in agreement with the Massoretic Text-1QIsa a is a case in point. Secondly, fragments that are seemingly less relevant will be discussed. The less helpful fragments from the Biblical books Proverbs and Job are taken as examples. Finally, highly significant textual differences, such as a fragment from Genesis 1 and one from the complicated books of Jeremiah, will be evaluated.

\section{Introductory Issues The problem}

The discovery at wadi Qumran in 1947 by a shepherd was arguably the most significant as far as biblical texts are concerned. ${ }^{1}$ After all, texts such as 1QIsa ${ }^{a}$ are more than a millennium older than the Textus Receptus. There are conspicuous correspondences between Massoretic Text (MT) and some Dead Scrolls. At first glance, 1QIsa ${ }^{a}$ seems identical to MT Isaiah; both have 66 chapters in the published volumes. However, when scrutinised, prominent differences in addition to correspondences become apparent.

This contribution will take a closer look at a number of Dead Sea manuscripts and/or fragments in order to determine their linguistic and exegetical value. The article will, firstly, address textual material that is largely in agreement with the MT -1QIsaa. Secondly, fragments that are on the face of it less relevant will be discussed. The 'insignificant' fragments from the Biblical books Proverbs and Job are cases in point. Finally, highly significant textual differences, such as a fragment from Genesis 1 and one from the books of Jeremiah, will be evaluated.

\section{Methodological issues}

This contribution will depart from the reality of textual plurality in the pre-common era (Tov 1985). According to this point of departure, the MT is one of the textual witnesses available (Septuagint [LXX], Tgg, Pesh, etc.) but not the most important one. Even so, MT is used as a basis of comparison. The Biblia Hebraica Stuttgartensia (BHS) edition is used for the Hebrew text (MT), DJD 32 for 1QIsa ${ }^{a}$ and the Rahlfs pocket edition for LXX.

\section{Textual material largely in agreement with the Massoretic Text (MT) \\ 1QIsa ${ }^{a}$}

As is well known, the books of Isaiah and the Psalms are well represented in the Dead Sea Scrolls. Of the first, there are two larger mss, $1 \mathrm{QIsa}{ }^{\mathrm{a}}$ and $1 \mathrm{QIsa}^{\mathrm{b}}$, as well as numerous fragments (Ulrich \& Flint 2010). 1QIsa a at first sight seems to be identical to MT Isaiah, for one thing, both have 66 chapters in the modern publications. ${ }^{2}$ Closer inspection reveals prominent differences. Firstly, the scribes and/or copyists were less meticulous than MT Isaiah's. ${ }^{3}$ The number of later handwritten marginal notes testifies to this (Ulrich \& Flint 2010:61 ${ }^{4}$ ). Secondly, there is evidence that the scroll was divided into two parts. In this regard, there is a clear gap of 3 lines at the end of chapter 33, which was used by Giese (1988:61) as main evidence for proposing a bisection (Part 1 = chapters 1-33 and Part $2=34-66$ ) in 1QIsa ${ }^{a}$. There is additional evidence of a dichotomy in this scroll.

\footnotetext{
1.By this statement, I do not intend to belittle the Nag Hammadi discoveries. The recent announcement in the press of a new discovery in the Judaean desert is too early to evaluate.

2.It must be remembered that the original publications did not contain chapter and verse indications.

3.The scribal/copyist activity at Qumran is not comparable to the Masoretes' meticulous work.

4.Ulrich and Flint (2010:61) find evidence of two Herodian period scribes' additions. 
This bisection can be observed from some orthographical characteristics of 1QIsa ${ }^{a}$ (Cook 1989, 1992). Data reworked in an electronic Qumran database (Cook 1988) as well as Logos 6, provide the necessary information. The first category is the aleph as mater lectionis used in various positions. The first example is the particle כי. There are 323 examples in this scroll and 328 occurrences in the Textus Receptus. Defective and plene forms are used simultaneously; however, the plene form (כיא), which does not appear at all in BHS, has been used in the majority of cases, namely 194 times according to Logos. In 129 instances the defective form is used. There is a definite pattern as far as these forms are concerned. In the first part of the scroll (1-33), כי occurs 123 times and the plene form כיא 34 times. In the second part, כיא $159^{5}$ times.

In chapters 34 through to 66 , there are only 4 cases of the defective form out of 129 occurrences. There is thus a concentration of plene forms in the second part of 1 QIsa ${ }^{a}$.

The interrogative particle מי occurs 63 times in 1QIsa and in 23 cases the spelling is plene. These are all concentrated in chapters 33-66.

The suffix $\mathrm{r}$ /occurs 134 times in 1QIsa ${ }^{\mathrm{a}}$ and in 5 cases (30:8; $34: 10,11 ; 62: 4$ and 66:10) has the aleph added to the he- הא. What is striking, firstly, is that all the plene forms are added after chapter 33. Secondly, not all the suffixes actually had the aleph added. The following pattern prevailed: without the aleph Isaiah $5: 14 ; 6: 13 ; 8: 21 ; 24: 6 ; 27: 4 ; 30: 32,33 ; 33: 24 ; 34: 17$; $37: 29 ; 42: 5 ; 51: 3 ; 56: 2 ; 59: 8$ and 65:19.

There is thus a pattern of sorts as far as 1QIsa ${ }^{a}$ is concerned, with plene forms being concentrated in the second half of the scroll. On the contrary, $1 \mathrm{QIsa}^{\mathrm{b}}$ consistently uses defective forms. This phenomenon is probably the result of different scribes.

According to some scholars, there can be no doubt that the dating of textual material is of crucial importance. Hurvitz (2006) phrases it as follows:

\begin{abstract}
Determining the historical age and chronological background of the literary compositions that make up the Hebrew Bible is a demanding undertaking which has lain at the heart of our discipline from its inception. Indeed, dating the biblical texts is indispensible for every aspect of research, textual, linguistic, literary, historical, theological, hence the persistent efforts invested over the years by Old Testament scholarship in dealing with chronological issues. (p. 192)
\end{abstract}

Not everybody agrees with this point of view. ${ }^{6}$ Concerning the value of orthography for introductory issues, scholars also have deviating views. Girdlestone (1892:176) held the opinion that issues of spelling could be useful to determine the age and authorship of sources. Whereas formerly scholars argued that $1 \mathrm{QIsa}{ }^{\mathrm{a}}$ seems to have been copied by more than

5.There are smaller discrepancies in the number of occurrences, which are the result of different interpretations of words. In 1QIsa 2:6, a scribe added a yod, and in 4:5, a whole phrase is missing in 1Qlsa $a^{a}$.

6.See the discussion by Naudé (2010:2), who operates from functional and formal approaches on language change. one person (Ulrich \& Flint 2010:61), there seems to be a consensus that one scribe was responsible for copying the whole book and that later revisers made some changes and added expansions (Ulrich \& Flint 2010:63). As stated above, Ulrich and Flint (2010:63) found evidence of scribal activity that can be dated to the Herodian period.

Cross and Freedman (1952:60) also thought that the study of orthography could be valuable for linguistic analyses. The problem with their work concerns the fragmented nature of their subject matter. Andersen and Forbes (1986:63) executed important research in this regard, but concentrated on the Hebrew Bible. This applies to James Barr (1989:2f.) also. He was highly sceptical of endeavours to find solutions to introductory questions via spelling characteristics. He followed a strictly descriptive approach without presenting historical solutions.

There are also more positive views regarding this issue. Martin (1958) took the Dead Sea Scrolls into account. He held the opinion that social factors in fact influenced scribal material. The environment of the scribe and/or copyist therefore also is a determinative factor. The standard research on 1QIsa ${ }^{a}$ and MT remains the book by Kutscher (1974). He also stressed the plurality of textual material at Qumran and suggested that the secluded geographical situation of Qumran should be accounted for by the researcher. Tov (1986) followed a historical approach in this regard. He is of the opinion that there existed two groups of scrolls at Qumran, which can be distinguished on account of their orthography. According to him, one group had a 'Qumran orthography' in which plene spelling systems predominated. The second group lacks such forms. It is immediately clear that it is difficult to classify $1 \mathrm{QIsa}^{\mathrm{a}}$ according to this criterion. Even though plene forms dominate in this scroll, defective ones appear abundantly. On the other hand, 1QIsab could fit this picture.

Hopefully, it has become clear that the large Isaiah scroll differs in various respects from MT. In my opinion, orthographic characteristics can be useful for addressing introductory issues, as demonstrated by Tov, Ulrich and Flint et al.

\section{'Insignificant' textual material Proverbs}

The paucity of textual material of the Dead Sea Scrolls for the books of Proverbs is a problem. Whereas for some books of the Hebrew Bible (e.g. Isaiah and the Psalms) in the Dead Sea Scrolls there are many texts and fragments available, for Proverbs only a few fragments are extant. However, there is a multitude of mss that attest to MT's.

\section{QProv ${ }^{\mathrm{a}}$ and 4QProv ${ }^{\mathrm{b} 7}$}

These fragments attest to some Hebrew variants. In Proverbs 1:32 מושבת there is a variant, testified to by 4QProva. 7.Cf Cook 2013 
According to De Waard (2008:31), it could be the result of metathesis. In 11:23, there is a variant, ע ב ד ה ה for appears in De Rossi (De Waard 2008:41). In 14:35, MT reads ועברתו, which in De Waard's (2008:45) opinion seems to be read in 4QProv ${ }^{b}$ as ועברתו. According to De Waard (2008:45), עבת in fact was the Vorlage for the LXX rendering. Chapter 8 contains a crucial variant, אמון (artificer) for אמוּן in verse 30 (De Waard 2008:14). In 11:7, there is a possible variant, for ותותוהלת which could entail a scribal error (see also 20:21).

4QProv ${ }^{\mathrm{b}}$ is fragmentary, but according to De Waard (2008:6) in at least five instances supports MT. These are 13:6; 14:32; $15: 2,24$ and 28 . He also thinks that 3 other cases probably are related to MT, namely 15:22, 26 and 31. In connection with ועבתו 14:35, there seems to be some relationship between 4QProv ${ }^{\mathrm{b}}$, LXX and Pesh.

\section{Job}

The discovery of fragments of the Hebrew of Job in the Dead Sea Scrolls has unfortunately not thrown light on the issue at stake. There are only a few smaller fragments of Job available. See 4QpaleoJobc in P.W. Skehan et al. (1992:155-157), Qumran Cave 4 IV Palaeo-Hebrew and Greek Biblical Manuscripts; Cf. also M. Abegg et al. (1999:590-593), The Dead Sea Scrolls Bible. The Oldest Known Bible Translated for the First Time into English.

It is a pity that these two books do not have more extant textual material available. The reason why there is a paucity of material of these two books is probably because they were not deemed significant books by the Essene community, at least not as much as Isaiah and the Psalms. In respect of LXX Proverbs, it would have been helpful as far as the difference in the order of chapters towards the end of the book is concerned, had there been additional Hebrew evidence. The only 'evidence' of a different text is the Septuagint, a text that has been freely rendered. As it stands, the hypothetical reconstruction of a different parent text remains just that.

\section{Significant textual material Genesis $4 Q G^{\text {Gen }}$}

The first chapter of Genesis has a complex history of origin and transmission (Schmidt 1964). The difference between MT and LXX testifies to that situation. There are numerous differences in the so-called Hexaemeron (vv. 1-31).

The following general structure can be reconstructed from the two versions (Cook 2001:317):

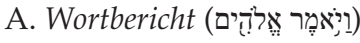

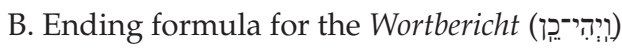

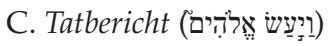

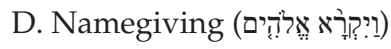

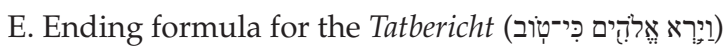

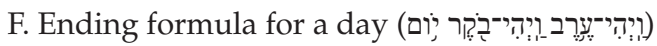

Focusing upon the Hebrew, one becomes aware that there is a discrepancy between the number of days (six) and the number of works (eight) completed during these days, which undermines this ideal structure. Moreover, this structure is not followed in all the days and/or works. The first day of creation does not have a Tatbericht. Likewise, the creation of man (vv. 26-30) has no ending formula following, neither Wort- nor Tatberichten. Finally, the name giving formulae are not found in connection with the third and fourth days. However, one can offer explanations for these apparent discrepancies. The non-existence of a Tatbericht in connection with the first day is natural because light was seen as the fundamental substance that came about solely by fiat (Westermann 1974:155). It is also possible that the author(s) of Gen 1 decided that the final work, man, should be included in the final expression of satisfaction in verse 31, טְוב This could act as an explanation why verses 26-30 have no ending formula.

Turning to the Septuagint, there are prominent differences in comparison with the Hebrew. For one thing, the Septuagint has a much more closely knit structure than MT. Firstly, the

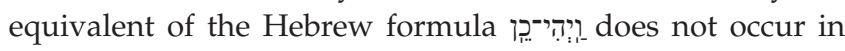
verse 6 following the Wortbericht, but in verse 7 after the Tatbericht. This applies also to the sixth work (vs 20), where it is not used at all in the MT. The main issue in this regard is whether these differences should be attributed to a deviating Vorlage or to the translator. In general, Rösel (1998:64) argues that some of the conspicuous differences are the result of harmonising by the Greek translator. However, there are differences of opinion on this issue. Hendel (1998, 1999), Brown $(1993,1999)$ and Cook (2001) argue that the differences between the MT and LXX in Genesis 1 are primarily the result of a deviating Hebrew Vorlage. It must be said that some scholars have nuanced views in this regard. Hendel (1998:121), for one, does interpret some of the additions as the result of harmonisations. However, he is clear on the issue at stake: 'In sum, it is more plausible and cogent methodologically to describe Gen-LXX, as, in general terms, a careful conservation of its Hebrew Vorlage than to explain each deviation from MT as the free composition of the Greek translator' (Hendel 1999:34).

This argument is primarily based upon a translation technical assumption. According to Hiebert (2007:1), 'The overall assessment of Genesis is that, lexically and syntactically, it is a strict, quantitative representation of its source text'. The Greek translation, in other words, is a relatively faithful rendering of the creation stories, which are related by means of the particle $\varepsilon^{\prime} \tau$ in Genesis 2:9 and 19. These chapters are also harmonised in that Genesis 1:26 and 2:18 both read the plural пои́ $\sigma \omega \varepsilon v$, whereas the Hebrew has a singular form in Genesis 2.

These discrepancies were problematic for Jewish exegetes. Ber R iv:6, for example, contains a discussion of this issue: 'He made - how remarkable! Surely it came into existence at God's word'. This Rabbinic passage also includes attempts to explain

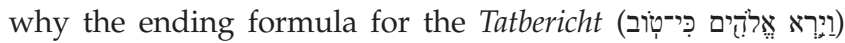


in verse 8 is omitted in MT. This applies also to verse 9 where TG Hagigah 12 (a) offers an explanation for the fact that the Tatbericht is missing. Clearly, the discrepancies were difficult for Jewish exegetes to understand, who then formulated some explanations. It should be remembered that for these exegetes, scripture was not discrepant at all.

What is remarkable is that many of the differences between LXX and MT are connected to water. I have argued that the Vorlage of MT differs from LXX's parent text because water played too prominent a role in the creation process (Cook 2001:319). This was unacceptable to a conservative Hebrew redactor who simply adapted his Hebrew text. Seen as such, the Tatbericht in verse 9 was not added in LXX in order to harmonise apparent discrepancies. The change was rather brought about in the parent text of MT. As a matter of fact, the LXX in general represents the Urtext of Genesis 1. This interpretation has theological ramifications. The MT places more focus on the sovereignty of God by bringing about ideologically inspired adaptations. This is another example of the fact that there should be an interactive relationship between textual and literary criticism (Cook 2009).

This explanation is primarily based on internal considerations - the Septuagintal evidence be deemed as primary evidence. But to return to the topic of this study, there fortunately exists fragmentary Qumran material, recently published by Davila (1990:8f, 1994:61) that underscores the Septuagint reading of verse 9 .

To be sure, the material is fragmentary and includes only three words, as well as the consonant $ש$ in separate lines. However, the third line contains a crucial Hebrew word, מקוה.

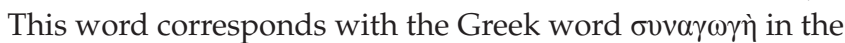
LXX, which in turn corresponds with the Old Latin against MT, SP, Pesh, V, TO, Neof, the FT and 4QGen ${ }^{\text {b }}$. These textual

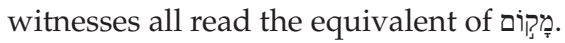

The mentioned Greek word appears twice in verse 9, once in the Wortbericht and once in the Tatbericht as can be observed in the text below.

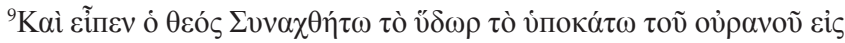

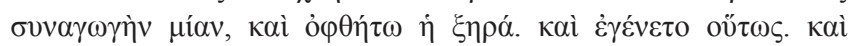

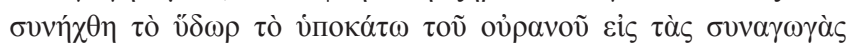

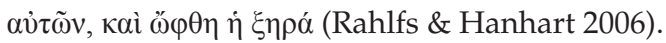

Hence, there existed a Hebrew Vorlage of the Tatbericht that underscores the interpretation I offered above. However, to be sure the Hebrew text is fragmentary, one of the golden rules of textual criticism is that textual evidence should be weighed and not counted.

This reconstruction has theological implications. Some Hebrew scribe, probably in Egypt where water plays a crucial role in creation stories - one example is the water god who inseminates the earth from above - deliberately removed the Tatbericht from Genesis 1:9, because it undermined the sovereignty of Elohim. In the formulation of a theology of the Septuagint version of Genesis, this could be a prominent topos (Cook 2010).

\section{The books of Jeremiah (4QJer ${ }^{d}$ )}

The books of Jeremiah have a complex transmission history, which is evidenced in the large number of extant texts. However, the differences between LXX and MT are significant; in this regard, it should also be remembered that the LXX of Jeremiah is circa 15\% shorter than MT. A prominent issue is the differences in the order of chapters vis-à-vis MT and other textual witnesses. This phenomenon occurs elsewhere in the LXX too. LXX Proverbs is a case in point. However, there is a significant difference between these translated units. As will be demonstrated below, LXX Jer has additional Hebrew evidence which is lacking in Proverbs.

As far as the differences in the order of chapters are concerned, the most striking example concerns the so-called Oracles against the Nations. Whereas in the MT, these prophecies are found at the end of the book (chs 46-51), in the Septuagint they occur approximately in the middle (chs 26-32). There are also other larger order differences, such as chapter 50 in MT that is chapter 43 in the LXX, the passage that I will discuss.

These textual differences are of determinative importance for an understanding of the Jeremiah collections. Depending on the approach followed by the interpreter, the crucial question in this regard would probably be which of these arrangements should be taken as the original. If one concentrated on the reception of these different texts in diverse contexts, then the original (or earlier) version of the description would probably be of less importance. However, as I demonstrated above, I am of the opinion that, in the process of reconstructing texts, one gathers significant exegetical perspectives (Cook 2009) that can be helpful in arriving at an understanding of the different texts.

Various reasons have been suggested for these remarkable differences. Diverging Hebrew Vorlagen are taken as the reason for these deviations by most scholars (Janzen 1973; Tov 1992a). Rudolph (1968), on the contrary, ascribes to the translator practically all deviations from the MT. Few scholars will today agree with this point of view.

Janzen (1973), who was probably the first scholar to address systematically the issue of Qumran Jeremiah, concluded that the Hebrew Vorlage of the LXX was very conservative and that it had been created not very far removed in time from the Urtext of Jeremiah (Janzen 1973:68). He also deems the LXX to be a better witness to the original text of Jeremiah than the MT, which in his view is expansionistic, and the end result of scribal activity of many manuscript generations (Janzen 1973:68). According to him, the Oracles against the Nations initially circulated separately and were only added to the finished book later (Janzen 1973:115).

As far as the position of a different parent text is concerned, Tov (1985) presents a nuanced position. He distinguishes between literary and textual criticism, arguing that biblical books grew stage by stage throughout a period of several generations (Tov 1992a:316). According to him, even when a book seemed to have attained a completed state, it was often 
re-edited in a revised edition (Tov 1992a:316). Contextual factors accordingly led to the existence of more than one edition of specific books because, after they were completed, they were accepted as final and remained in use. However, later 'revised editions' of the books, which were intended to replace the earlier ones, were prepared and circulated. Because the process of substitution was not complete, the early editions did not simply disappear. Consequently, in Palestine the new edition that was later to become the MT.

In line with this explanation, Tov therefore maintains that Jeremiah LXX is the result of a different Hebrew Vorlage, in the sense of a different edition to the Massoretic parent text. Edition I contains the LXX source text, and Edition II that which later became the MT and which was almost identical to the edition contained in some of the ancient versions ( $\mathrm{Tg}$, Pesh and Vul), only partly replaced the earlier texts. They were still deemed holy texts by certain communities. Thus, the earlier editions remained in use in places that were not central from a geographical and sociological point of view, such as the Qumran repository of texts and the various manuscripts from which the Greek translation was prepared in Egypt (Tov 1992a:316).

The problem with this suggestion is that it is speculative. However, the situation changed dramatically in the wake of discoveries in the Judaean desert. This applies especially to

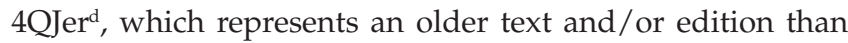
the Vorlage of the MT.

The following fragment has been reconstructed by Tov (1992b:538):

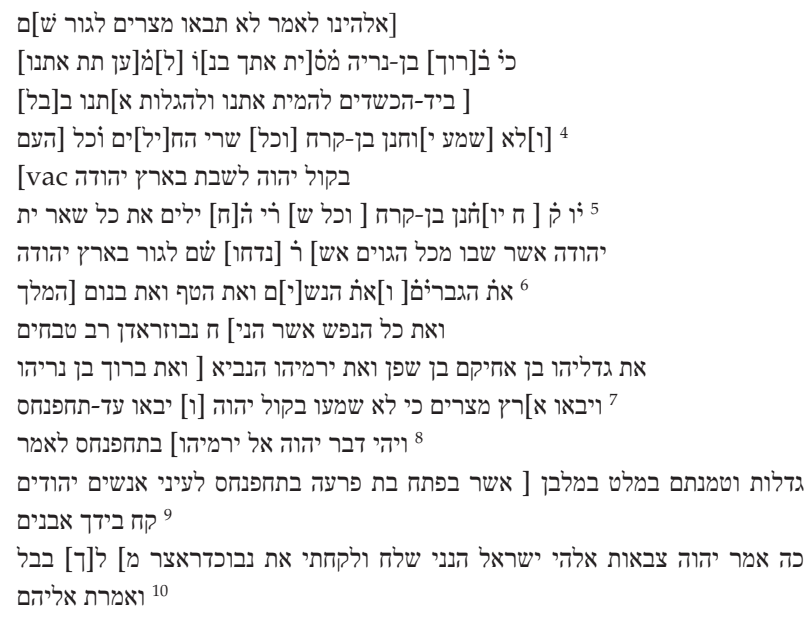

\section{50:2-10}

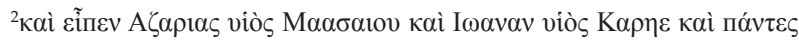

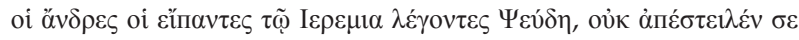

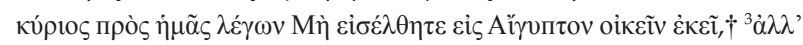

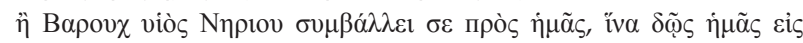

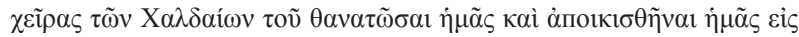

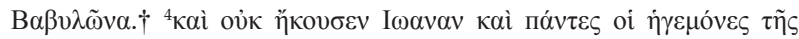

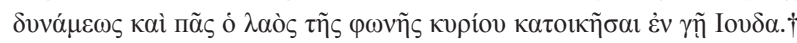

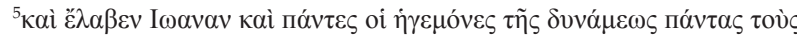

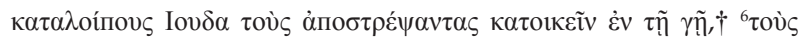

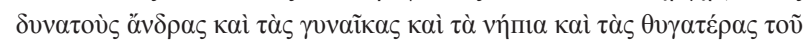

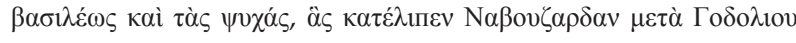

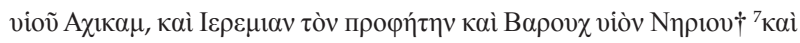

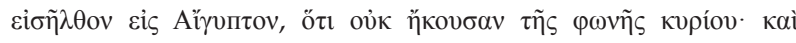

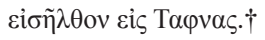

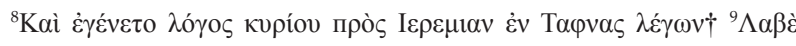

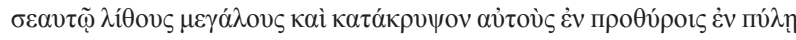

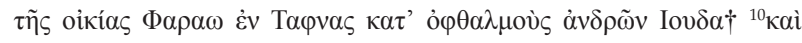

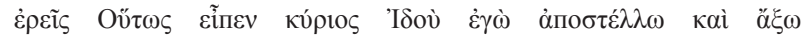

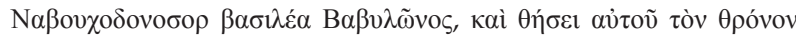

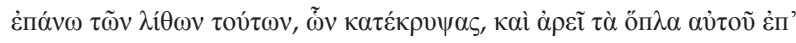

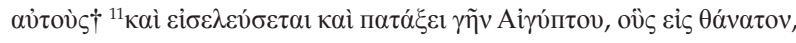

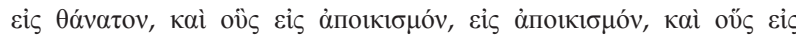

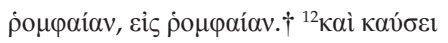

\section{NETS}

And it happened, when Jeremias stopped saying to the people all the words of the Lord, with which the Lord had sent him to them - all these words ${ }^{2}$ - then Azarias son of Maasaeas said, and Joanan, the son of Karee, and all the men who had spoken to Jeremias, saying. 'Lies! The Lord did not sent you to us, to say. "Do not enter into Egypt to live there", ${ }^{3}$ but Barouch son of Nerias is inciting you against us in order that you hand us over into the hands of the Chaldeans that they put us to death and that we be exiled to Babylon. ${ }^{4}$ And Joanan, and all the leaders of the force and all the people did not obey the voice of the Lord, to settle down in the land of Juda. ${ }^{5}$ And Joanan, and all the leaders of the force took all those remaining of Juda who had returned to settle down in the land $-{ }^{6}$ the mighty men and the women the rest and the daughters of the king, and the souls whom Nabuzardan had left with Godolias son of Achikam and the prophet Jeremias and Baruch son of Nerias. ${ }^{7}$ And they entered into Egypt, because they did not obey the voice of the Lord. And they entered into Taphnas. ${ }^{8}$ And a word of the Lord came to Jeremias in Taphnas, saying, ${ }^{9}$ Take some large stones for yourself, and hide them in the entrance to Pharao's house in Taphnas in the sight of the men of Juda, ${ }^{10}$ and you will say, Thus did the Lord say: Behold, I am sending for and will bring Nabuchodonosor of Babylon, and he will set his throne over these stones that you have hidden, and he will raise his weapons against them. (Jr 43:1-11)

For the sake of completeness, I briefly compare the Greek text with 4 QJer ${ }^{\text {d }}$ Firstly, these two texts agree largely. However, there are some conspicuous differences. The explication of Baruk as the son of Nariyahu in verse 3 agrees with MT. However, it should rather be seen as an internal harmonisation

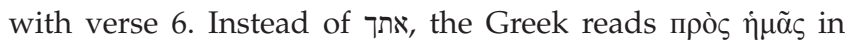

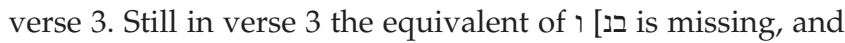
in verse 10, the equivalent of צבאות אלהי ישראל is omitted. In verse 7, the LXX refers to 'daughters', whereas 4QJer ${ }^{d}$ reads 'sons'. LXX agrees with MT in this case. The pronoun $\sigma \varepsilon \alpha v \tau \tilde{\varphi}$ is used as equivalent for בידך in verse 9. These minor differences need not be taken as Vorlage differences.

Finally, a few observations are in order. Firstly, this fragment is primary evidence of a Hebrew text that corresponds with the Septuagint. Secondly, the Hebrew text is very fragmentary and should be approached carefully. Thirdly, having said that, the reconstruction is credible. Paleographic research is precision work. The leather fragments are carefully measured 
and words calculated and fit with precision. Moreover, Emanual Tov is a specialist in this regard. Fourthly, there are conspicuous characteristics in this fragment. The explication of individuals is indicated in red in the text and is a typical trait of MT. Finally, of great significance is the fact that 4QJer ${ }^{\mathrm{d}}$ and 4QJer ${ }^{a}$ both 'reflect the Hebrew text from which the Septuagint was translated, not just in small details, but also in the recensional differences in which the Septuagint differs from the MT (shorter text and differences in sequence)' (Tov 1992b:532).

\section{Conclusion}

The Dead Sea Scrolls indeed are holding up to their reputation after more than 65 years of research, and we will have to see whether this can be said of the latest discovery in the Judaean desert. This study demonstrated that some scrolls correspond to a large extent with the MT - 1QIsa ${ }^{a}$ is an appropriate example. It also showed that fragments should be approached carefully. There are insignificant fragments like those found in the books of Proverbs and Job, at least as far as the theme of this study is concerned. However, fragments from the books of Genesis and Jeremiah proved to be decisive for determining whether there existed deviating Semitic Vorlagen. This in turn opened significant text-critical and exegetical perspectives.

\section{Acknowledgements Competing interests}

The author declares that he has no financial or personal relationships which may have inappropriately influenced him in writing this article.

\section{References}

Abegg, M., 1990, The Dead Sea Scrolls Bible. The oldest known Bible translated for the first time into English, Harpers, San Francisco, CA.

Andersen, F.L. \& Forbes, A.D., 1986, Spelling in the Hebrew Bible, Biblical Institute Press, Rome.

Barr, J., 1989, The variable spellings of the Hebrew Bible, the Schweich Lectures 1986 Alden Press, Oxford.

Brown, W., 1993, Structure, role, and ideology in the Hebrew and Greek texts of Genesis 1:1-2:3. SBLDS 132, Scholars Press, Atlanta, GA.

Brown, W., 1999, 'Reassessing the text-critical value of Genesis 1: A response to Martin Rösel', BIOSCS 32, 35-39.

Cook, J., 1988, 'The Qumran (Biblical Scrolls) Data Base', JNSL 14, 27-40.

Cook, J., 1989, 'Orthographical peculiarities in the Dead Sea Scrolls', RQXIV(2), 293-305.

Cook, J., 1992, 'The Dichotomy of 1QIsaa', in Z.J. Kapera (ed.), Intertestamental essays in honour of Jósef Tadeusz Milik, pp. 7-24, Enigma Press, Krakow, Poland.
Cook, J., 2001, 'The Septuagint of genesis: Text and/or tradition?', in A. Wenin (ed.), Studies in the book of genesis. Literature, redaction and history, pp. 315-329, Uitgeverij Peeters, Leuven.

Cook, J., 2009, 'The relationship between textual criticism, literary criticism and exegesis - An interactive one?', Textus 24, 119-132.

Cook, J., 2010, 'Towards the formulation of a theology of the Septuagint', in A. Lemaire (ed.), Congress volume Ljubljana 2007, pp. 621-640, Brill, Leiden, Vetus Testamentum supp. 133.

Cook, J., 2013, 'Proverbs', in A. Lange and E. Tov (eds.), The textual history of the Hebrew Bible, Brill, Leiden, 2013.

Cross, F.M. \& Freedman, D.N., 1952, Early Hebrew orthography, American Oriental Society, New Haven, CT.

Davila, J.R., 1990, 'New Qumran readings for genesis one', in H.W. Attridge, J.J. Collins and T.H. Tobin (eds), Of Scribes and Scrolls. Studies in the Hebrew Bible, Intertestamental Judaism, and Christian Origins, presented to John Strugnell, pp. 3-11, University Press of America, Lanham, MD.

Davila, J.R., 1994, '4QGen ${ }^{\text {h1', }}$, in, E. Ulrich, F.M. Cross, J.R. Davila, N. Jastrum, J.E. Sanderson, E. Tov, J. Strugnel, Discoveries in the Judaean Desert XII, Qumran Cave 4 VII, Genesis to Numbers, pp. 60-61, Clarendon Press, Oxford.

De Waard, J., 2008, משלי Proverbs: Introduction and commentaries on proverbs, BHQ 17, Deutsche Bibelgesellschaft, Stuttgart.

Giese, G.L., 1988, 'Further evidence for the Bisection of 1 Qlsa $a^{a}$ ', Textus 14, 55-70.

Girdlestone, R.B., 1892, The Foundation of the Bible. Studies in old Testament Criticism, Eyre and Spottisworde, London.

Hendel, R.S., 1988, The text of genesis 1-11, Textual studies and critical edition, Oxford University Press, Oxford.

Hendel, R.S., 1999, 'On the text-critical value of Septuagint genesis: A reply to Rösel', BIOSCS 32, 31-34.

Hiebert, R.V.J., 2007, 'Genesis: To the reader', in A. Pietersma and B.G. Wright (eds.), A new English translation of the Septuagint, pp. 1-42, Oxford University Press, Oxford.

Hurvitz, A., 2006. 'The recent debate on Late Biblical Hebrew: Solid data, experts' opinions, and inconclusive arguments', Hebrew Studies 47, 191-210. http:// dx.doi.org/10.1353/hbr.2006.0005

Janzen, J.G., 1973, Studies in the text of Jeremiah, HSM 6, Harvard University Press, Cambridge MA.

Kutscher, E.Y., 1974, The language and linguistic background of the Isaiah Scroll $\left(1 Q I s a^{a}\right)$, Brill, Leiden.

Martin, M., 1958, The scribal character of the Dead Sea Scrolls, Peeters, Louvain.

Naudé, J.A., 2010, 'Linguistic dating of Biblical Hebrew texts: The chronology and typology debate', Journal of Northwest Semitic Languages 36(2), 1-20.

Rahlfs, A., \& Hanhart, R. (eds.), 2006, Septuaginta: SESB edition, Deutsche Bibelgesellschaft, Stuttgart.

Rösel, M., 1998, 'The text-critical value of Septuagint-genesis', BIOSCS 31, 62-70.

Rudolph, W., 1968, Jeremia, HAT, Mohr, Tübingen.

Schmidt, W.H., 1964, Die Schöpfungsgeschichte der Priesterschrift, WMANT, 17 Neukirchener Verlag Neukirchen-Vluyn.

Skehan, P.W., E. Ulrich, J.E. Sanderson, M.C. Douglas, 1992, '4QpaleoJobc', in Qumran Cave 4 IV Palaeo-Hebrew and Greek Biblical Manuscripts, pp. 155-157, Oxford University Press, Oxford.

Tov, E., 1985, 'The literary history of the Book of Jeremiah in the light of its textual history', in J.H. Tigay (ed.), Empirical models for biblical criticism, pp. 211-237, Pennsylvania Press, Philadelphia, PA.

Tov, E., 1986, 'The orthography and language of the Hebrew Scrolls found at Qumran and the Origin of these Scrolls', Textus 13, 31-49.

Tov, E., 1992a, Textual criticism of the Hebrew Bible, Fortress Press, Minneapolis, MN.

Tov, E., 1992b, 'Three fragments of Jeremiah from Qumran Cave 4', RQ 15, 531-541.

Ulrich, E. \& P.W. Flint, with a contribution by Martin. G. Abegg jr, 2010, Qumran Cave 1, II. The Isaiah Scrolls Part 2: Introductions, commentary, and textual variants, Clarendon Press, Oxford.

Westermann, C., 1974, Genesis I. Band genesis 1-11. BKAT, Neukirchener Verlag, Neukirchen-Vluyn. 